International Journal of Business Management and Economic Review

Vol. 4, No. 06; 2021

ISSN: 2581-4664

\title{
THE EFFECT OF COMPANY RISK, PROFIT GROWTH, AND FINANCIAL LEVERAGE ON STOCK RETURN AND ITS IMPLICATIONS ON EARNING RESPONSE COEFFICIENT OF FINANCIAL SECTOR COMPANIES LISTED IN INDONESIA STOCK EXCHANGE (IDX)
}

\author{
Rachma Eka Putri, Zuraida and Nuraini Anzib \\ Master of Accountancy Program, Faculty of Business, Universitas Syiah Kuala, Banda Aceh,Indonesia
}

http://doi.org/10.35409/IJBMER.2021.3340

\begin{abstract}
This study aims to examine the effect of corporate risk, profit growth, and financial leverage on stock returns and their implications on earning response coefficients in financial sector companies of the Indonesia Stock Exchange (IDX). The population in this study are financial sector companies on the Indonesia Stock Exchange. This study uses a purposive sampling method and the sample selected are 66 companies. The analytical method used in this study is path analysis and it employed the pooled data. The results showed that partially the company's risk and profit growth have an effect on stock returns and on the earnings response coefficient. Meanwhile, the financial leverage has no effect on stock return and earning response coefficients. In addition, the research outcome using path analysis partially shows that stock return mediates the relationship between corporate risk and earning response coefficients, and do not mediate the relationship between earning growth and financial leverage against earning response coefficients.
\end{abstract}

Keyword: Corporate Risk, Profit Growth, Financial Leverage, Stock Return, Profit Response Coefficie.

\section{INTRODUCTION}

Financial reports published in the capital market must provide relevant information or can reveal the actual condition of the company so that it is beneficial to the general public and decision makers. The main information desired by investors (investors / potential investors) is about company profits. Often investors make net income as a benchmark for investing (Heze, 2016), so it is not uncommon for management to know the company's internal conditions to practice earnings manipulation with the intention of attracting investors to invest their funds in their companies (Irawati, 2012). Thus, investors must scrutinize the published information. One indicator that the information is relevant is when the investor reacts when information is announced, which can be observed from stock price movements (Naimah, 2008).

The movement of the Composite Stock Price Index (CSPI) will affect market returns because it serves as an indicator of market trends, which means the index movement describes the market conditions at a time (Darmadji and Fakhruddin, 2011:129). This was evidenced by the decline in the JCI's performance in mid-2013 and falling to the lowest level in August (Sari, 2014). JCI in 


\section{International Journal of Business Management and Economic Review}

Vol. 4, No. 06; 2021

ISSN: 2581-4664

September began to recover by $2.89 \%$. Although in November it experienced a decline of $5.64 \%$, in December it again increased by $0.45 \%$ and continued to stabilize in 2014 and so on (Financial Services Authority, 2013). Based on this phenomenon, the profit information needed by investors is quality earnings information that can be measured using earnings response coefficient (ERC) (Murwaningsari, 2008).

Putri and Azhari (2017) stated that ERC is very useful in fundamental analysis to calculate the value of actual shares using company financial data. If you know the ERC value, investors have calculated earnings expectations well before the financial statements are reported so investors will have more information in analyzing periodic earnings figures. Profit that occurs will affect the rate of return of shares for investors. The strength of profits in each company will have different variations in influencing stock returns (Arif, 2016). Sukamulja (2017: 82) mentions capital gains and dividends as return on investment. In a limited liability company (PT), the profits earned will be allocated to retained earnings and dividends. Profits allocated to retained earnings are used for re-investment while dividends will be distributed to investors in the form of cash dividends and stock dividends (Barli, 2016).

Collins and Kothari (1989) state that the market response to the profits of each company can vary, both between companies and between times. From several studies conducted, ERC is influenced by many factors, not only concerning financial information factors but also nonfinancial factors (Arif, 2016). Such risks are often associated with deviations from the results received with the expected. Riyanto (2011:156) states that the risk in investing means that the return received in the future cannot be known but can only be expected, so that the more risky expected rate of return will reduce investor reaction so that ERC will be low. The results of the research conducted by Collins and Kothari (1989), Delvira and Nelvirita (2013), Mulyani, Asyik, and Andayani (2007), and Naimah (2008) state that the risk has a negative relationship with ERC. Unlike the research conducted by Nasihah (2014), Husiano and Suratno (2008) which stated that the risk did not affect the ERC. This is due to the company's consistent performance so that the risk does not concern investors in making decisions.

Other factors that affects ERC are profit growth and financial leverage. Profit growth explains the company's future growth prospects. Brigham and Houston (2010: 151) state that a company that is considered good by investors is a company with profit and safe cash flow and experiencing growth. If the condition of the company is constantly stable, then investors believe that the company has done a good job so that the company's stock price rises and investors get the return as expected. Thus, earnings growth and ERC have a positive relationship (Collins and Kothari, 1989). The results of similar studies were also proven by research conducted by Winisaputri, Ethika, and Darmayanti (2014) and Naimah and Utama (2006) which showed that earnings growth had an effect on the ERC. In contrast to the results of Irawati (2012), Erkasi (2009), and Dira and Astika (2014) who stated that earnings growth did not affect the ERC.

Companies with a high degree of leverage have a greater liability than equity so that the 


\section{International Journal of Business Management and Economic Review}

Vol. 4, No. 06; 2021

ISSN: 2581-4664

quality of the company and its prospects are not good in the future (Haris and Raviv, 1990). This is because investors assume that the profits generated later will only benefit the creditors so that investors respond negatively to the company. This is similar to the results of a study conducted by Diantimala (2008), Winisaputri et al. (2014), and Dhaliwal, Lee, and Fargher (1991) which show that the level of leverage influences and is negatively related to ERC. Unlike the research conducted by Delvira and Nelvirita (2013) which stated that leverage does not affect the ERC. This is because not always the use of debt in the source of corporate funds will cause bankruptcy. Agus (2001) in Delvira and Nelvirita (2013) states that the use of debt can provide in the form of tax protection, because interest payments as a tax deduction, the profits obtained by investors will be higher.

\section{LITERATURE REVIEW AND HYPOTHESIS DEVELOPMENT ERC}

Information about earnings in financial statements will affect investors' expectations about the company in generating future profits, and will be reflected in changes in stock prices that occur in the capital market (Riyatno, 2007). Thus, ERC is used to measure how much the market reacts to information about the company at the time of the issuance of financial statements, especially information about company profits.

\section{Stock Return}

Stock return is stock income and changes in stock price value, where the higher the price change of a stock, the higher returns will be generated (Abror and Sadeli, 2014).

\section{Company Risk}

Understanding of risk is that there are a number of possibilities, both known results or the possibility of occurrence of events among all events that may occur (Riyanto, 2011:155). Systematic risk is the overall risk in the market and cannot be eliminated by diversification (investment in various types of stocks). If systematic risk arises and occurs, all types of shares will be affected so that investments in 1 or more types of shares cannot reduce losses. Examples of systematic risk are economic recession, rising inflation, and interest rate risk (Darmadji and Fakhruddin, 2011:162).

\section{Profit Growth}

Profit growth explains future earnings growth. Market assessments (investors) of the possibility of growing a company can be seen from the stock price formed as an expectation value for future benefits to be obtained. Shareholders or investors will give a greater response to companies with the possibility of high growth (Indra, Zuhron, and Rosianawati, 2011). Profit measurement is not only important for determining company performance but also important as information for sharing profits with shareholders and determining investment policies.

\section{Financial Leverage}




\section{International Journal of Business Management and Economic Review}

Vol. 4, No. 06; 2021

ISSN: 2581-4664

According to Ardiyos (2004: 153), leverage ratio is defined as a measure of debt to the total capitalization of a company. The higher this ratio identifies excessive debt, which indicates the possibility of a company being unable to generate sufficient income / profit to fulfill its debt obligations.

\section{The Effect of Company Risk on Stock Return}

Basically, people who want to invest are to make a certain amount of money or a maximum level of profit, and a broader goal is to improve the welfare of investors. Investment choices cannot only rely on the expected level of profit but also the risk. Return and risk have a positive relationship, the greater the risk that must be borne, the greater the return that is compensated (Hartono, 2003). The sensitivity of the level of share profits to market changes is called the beta stock. The greater the fluctuation of stock returns on market returns, the greater the beta of the stock. Likewise, on the contrary, the smaller the fluctuations in stock returns to market returns, the smaller the beta stock of an investment has risk, meaning that the investment will not provide a definite advantage.

\section{The Effect of Profit Growth on Stock Return}

According to Harahap (2010:309), Earning growth is a ratio that describes the percentage growth of company posts from year to year. If the stock price reflects the capitalization of expected profits in the future, then an increase in profit will increase stock prices and total stock capitalization. Increased profitability shows that the company's performance is getting better and will gain investor trust in the company so that stock prices will rise. Conversely, a decrease in profits will reduce stock prices and total stock capitalization so that it will harm investors. This shows that profit growth has an influence on stock returns.

\section{The Effect of Financial Leverage on Stock Return}

The high leverage ratio shows that the company's performance is getting worse, because the level of dependence of the company's capital on outside parties is getting bigger. Thus, if the company's leverage ratio is high, the company's stock price will be low because if the company earns a profit, the company tends to use the profit to pay its debt compared to dividend dividends (Dharmastuti, 2004 in Mariani et al., 2016), thereby reducing investor interest in invest in. This shows that leverage affects stock returns.

\section{The Effect of Company Risk on Earnings Response Coefficient}

Risks that cannot be diversified or eliminated are referred to as market risk or general risk or systematic risk. Systematic risk (systematic risk) is a variation in the development of shares/portfolios related to changes in development in the overall market (Brigham and Houston, 2010:346). Large market risks will provide information for investors to be careful in making 


\section{International Journal of Business Management and Economic Review}

Vol. 4, No. 06; 2021

ISSN: 2581-4664

investment decisions. According to Naimah (2008), ERC is an inverse function of systematic risk in various models with an empirical relationship between risk and profit variable. Low risk stocks will have a high ERC, and vice versa, stocks that have a high risk will have a low ERC. That is because the information on the profits delivered will be reacted positively by the market, so that the company's ERC is high. This shows that risk has an influence on the ERC.

\section{The Effect of Profit Growth on the Earning Response Coefficient}

Profit growth explains the company's future growth prospects. The growing opportunity faced by the company in the future is a good prospect that will bring profit to the company. Stable profit increase shows that the company's profit growth is good, if the greater the chance of growing the company, the higher the chance the company gets or adds to the profits the company gets in the future (Mulyani et al, 2007). Collins and Kothari (1989) state that companies that have a greater chance of growth will have a high ERC. This shows that profit growth has an effect on the ERC.

\section{The Effect of Financial Leverage on Earning Response Coefficient}

Harris and Raviv (1990) stated that the amount of debt shows the quality of the company and the prospects that are not good in the future. Then the parties who benefit are debtholders, so investors will respond negatively to the company. Because of the assumption that investors profit in the future, it only benefits the creditors. Companies with high levels of leverage have greater liabilities than equity, therefore the ERC can decrease. This shows leverage affects the ERC.

\section{The Effect of Stock Return on Earning Response Coefficient}

Brigham and Houston (2010: 151) state that companies that are considered good by investors, namely companies with profit and safe cash flow and continue to experience growth, are sold with a high book value ratio compared to companies with low returns. The higher the book value ratio, the more expensive the price per share so that the greater the profit provided to shareholders / investors and allows an increase in the amount of dividends received (Sukamulja, 2017:53). The reported earnings have a market power of response. The strong market reaction to earnings information is reflected in the high ERC that shows reported quality earnings. Conversely, the low ERC indicates that profits are less informative for investors to make investment decisions. Thus, the higher the ERC level, the higher the stock return that can be expected from the increase in profits (Imroatussolihah, 2013). Based on these statements, the stock returns affects on ERC.

\section{The Effect of Company Risk on Earnings Response Coefficient through Stock Return}

Budialim (2013), Ismayanti and Yusniar (2014) and Aufa (2013) conducted a study and showed the results that risk has an effect on stock returns. Based on the explanation on the subsection of the effect of stock returns on earnings response coefficients, it was concluded that stock returns have an effect on ERC, where the higher expected stock returns from the increase in 


\section{International Journal of Business Management and Economic Review}

Vol. 4, No. 06; 2021

ISSN: 2581-4664

corporate profits, the higher the ERC value. The results of the study conducted by Collins and Kothari (1989), Delvira and Nelvirita (2013), Mulyani et al. (2007), and Naimah (2008) state that risk has a negative relationship with ERC. Thus, the hypothesis can be formulated that the risk of the company affects the ERC through stock returns.

\section{The Effect of Profit Growth on the Earning Response Coefficient through Stock Return}

Riauwaty (2014) and Margaretha and Damayanti (2008) conducted research and obtained the results that earnings growth had an effect on stock returns. Based on the explanation on the sub-section of the effect of stock returns on earnings response coefficients, it was concluded that stock returns have an effect on ERC, where the higher expected stock returns from the increase in corporate profits, the higher the ERC value. Naimah and Utama (2006), Mulyani et al. (2007), Indra et al. (2011), Winisaputri et al. (2014), and Roni (2017) conducted a study that showed that earnings growth had a positive effect on ERC. Thus, a hypothesis can be formulated that earnings growth has an effect on ERC through stock returns.

\section{The Effect of Financial Leverage on Profit Response Coefficient through Stock Return}

Mariani et al. (2016), and Putra and Dana (2016) conduct research and show the results that leverage affects stock returns. Based on the explanation on the sub-section of the effect of stock returns on earnings response coefficients, it was concluded that stock returns have an effect on ERC, where the higher expected stock returns from the increase in corporate profits, the higher the ERC value. Dhaliwal et al. (1991), Diantimala (2008), Winisaputri et al. (2014), Imroatussolihah (2013), and Nugroho and Sukhemi (2015) conducted a study that showed results that financial leverage had an effect on the ERC. Thus, a hypothesis can be formulated that financial leverage has a negative effect on ERC through stock returns.

Based on the previous description, the research framework can be seen in Figure 1 below:

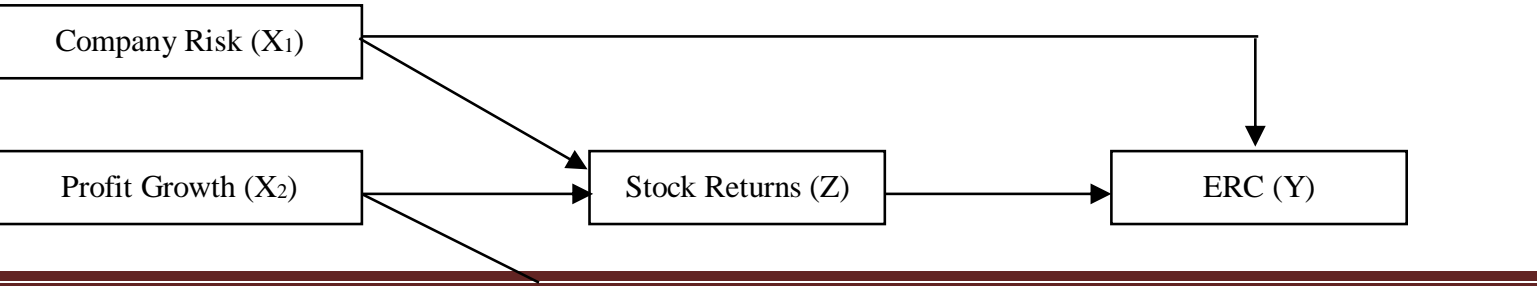




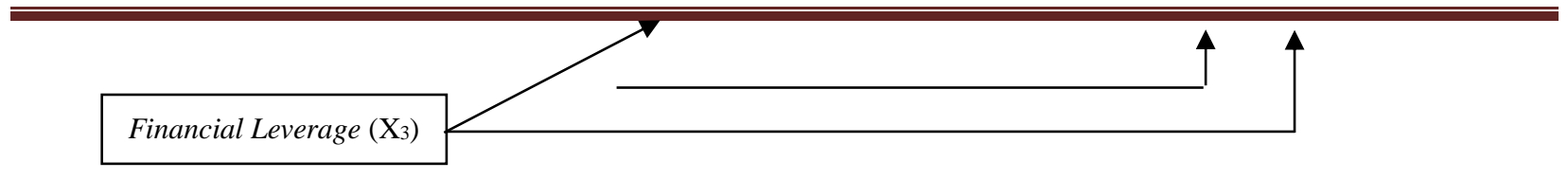

Figure 1. Research Framework

\section{Hypothesis}

Based on the problems, literature review and schema framework that was stated earlier, the hypotheses tested in this study are as follows:

$\mathrm{Ha}_{1}$ : Company risk influences stock return.

$\mathrm{Ha}_{2}$ : Profit Growth affects stock return.

$\mathrm{Ha}_{3}$ : Financial leverage influences stock return.

$\mathrm{Ha}_{4}$ : Company risk affects the ERC.

$\mathrm{Ha}_{5}$ : Profit growth affects the ERC.

$\mathrm{Ha}_{6}$ : Financial leverage affects the ERC.

$\mathrm{Ha}_{7}$ : Stocks returns affects the ERC.

$\mathrm{Ha}_{8}$ : Company risk affects ERC through stocks return.

$\mathrm{Ha}_{9}$ : Profit growth has an effect on ERC through stock return.

$\mathrm{Ha}_{10}$ : Financial leverage affects the ERC through stock return.

\section{RESEARCH METHOD}

The population in this study were all companies in the financial sector on the Indonesia Stock Exchange. In this study the sample was obtained using a purposive sampling technique (Now and Bougie, 2017: 67), with the following criteria: (1) financial sector companies listed on the Stock Exchange from 2014-2016; (2) companies that publish complete financial statements as of December 31 from 2014-2016; and (3) companies whose shares are actively traded on the IDX from 2014-2016. Based on these criteria obtained 66 companies as the research sample with observation years for 3 years, then the total observations were 198 observations. The data used in this study is secondary data, namely Indonesian Capital Market Directory (ICMD).

Measurement of each variable in this study, namely:

1. ERC (Y). ERC is obtained by doing several calculation stages.

a. Calculation of CAR.

Where :

$$
\mathrm{CAR}_{\mathrm{it}}=\sum \mathrm{AR}_{\mathrm{it}}
$$

$\mathrm{CAR}_{\mathrm{it}}$ : Cumulative Abnormal Company Return i during the event periode $\mathrm{t}$, which is from $\mathrm{t}-5$ to $\mathrm{t}+5$

$\mathrm{AR}_{\mathrm{it}} \quad$ : Abnormal Return for shares $\mathrm{i}$ in the event period $\mathrm{t}$, which is from $\mathrm{t}-5$ to $\mathrm{t}+5$ (Jogiyanto, 2010:137) 


\section{b. Calculation of Abnormal Return.}

$$
\mathrm{AR}_{\mathrm{it}}=\mathrm{R}_{\mathrm{it}}-\mathrm{R}_{\mathrm{mt}}
$$

Where :

$\mathrm{AR}_{\mathrm{it}} \quad$ : Abnormal return on company $\mathrm{i}$ in period $\mathrm{t}$

$\mathrm{R}_{\mathrm{it}} \quad$ : Company daily return $\mathrm{i}$ in period $\mathrm{t}$.

$\mathrm{R}_{\mathrm{mt}} \quad$ : Return of market index in period $\mathrm{t}$.

(Jogiyanto, 2010:580)

c. Calcualation of Actual Return.

$$
\mathrm{R}_{\mathrm{it}}=\frac{P_{\mathrm{it}}-P_{i t-1}}{P_{i t-1}}
$$

Where :

$\mathrm{R}_{\mathrm{it}} \quad$ : Company stock return actual i on day $\mathrm{t}$.

$\mathrm{P}_{\mathrm{it}} \quad$ : The closing price of a company $\mathrm{i}$ on the day $\mathrm{t}$

$\mathrm{P}_{\mathrm{t}-1} \quad$ : Stock price of closing company i on day $\mathrm{t}-1$

(Jogiyanto, 2010:580)

d. Calcualation of Market Return .

$$
\mathrm{R}_{\mathrm{mt}}=\frac{I H S G_{t}-I H S G_{t-1}}{I H S G_{t-1}}
$$

Where :

$\mathrm{R}_{\mathrm{mt}} \quad$ : Daily market return on day $\mathrm{t}$

$\mathrm{IHSG}_{\mathrm{t}}$ : Joint stock price index on day $\mathrm{t}$

IHSG $_{\mathrm{t}-1}$ : Joint stock price index on day $\mathrm{t}-1$

(Jogiyanto, 2010:103)

e. Calculation of UE.

$$
\mathrm{UE}_{\mathrm{it}}=\left(\mathrm{E}_{\mathrm{it}}-\mathrm{E}_{\mathrm{it}-1}\right) / \mathrm{E}_{\mathrm{it}-1}
$$

Where :

$\mathrm{UE}_{\mathrm{it}} \quad$ : Unexpected earning of the company $\mathrm{i}$ in the period $\mathrm{t}$

$\mathrm{E}_{\text {it }} \quad$ : Company accounting profit $\mathrm{i}$ in period $\mathrm{t}$

$\mathrm{E}_{\mathrm{it}-1} \quad$ : Company accounting profit $\mathrm{i}$ in the previous period $\mathrm{t}-1$

(Indra et al., 2011)

f. Calculation of ERC.

$$
\mathrm{CAR}_{\mathrm{i}(1,12)}=\beta_{\mathrm{o}}+\beta_{1} \mathrm{UE}_{\mathrm{i} . \mathrm{t}}+\varepsilon
$$

Where :

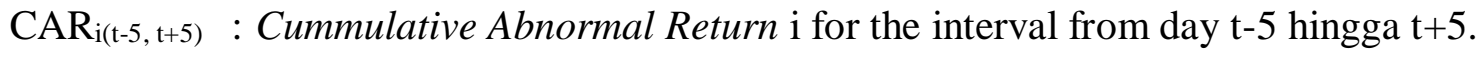
$\beta_{0} \quad$ : Constants

$\beta_{1} \quad$ : ERC

$\mathrm{UE}_{\mathrm{i} . \mathrm{t}} \quad$ : Non-expected profit of company $\mathrm{i}$ in period $\mathrm{t}$ 
International Journal of Business Management and Economic Review

Vol. 4, No. 06; 2021

ISSN: 2581-4664

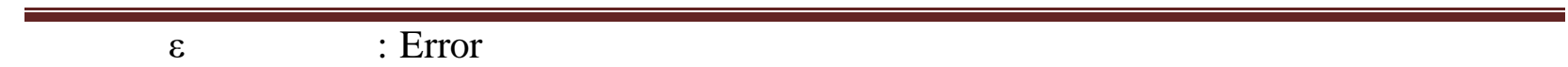

2. $\quad$ Stock Returns $(\mathrm{Z})$

$$
R_{i}=\frac{\left(P_{t}-P_{t-1}\right)+D_{t}}{P_{t-1}} \times 100 \%
$$

Where :

$\mathrm{R}_{\mathrm{i}} \quad$ : Stock Return

$\mathrm{P}_{\mathrm{t}} \quad$ : Stock Price in period $\mathrm{t}$

$\mathrm{P}_{\mathrm{t}-1}$ : Stock Price in period $\mathrm{t}-1$

$\mathrm{D}_{\mathrm{t}} \quad$ : Dividend distributed in period $\mathrm{t}$

(Jogiyanto, 2010:207), (Sukamulja, 2017:83)

3. Company Risk (X1)

$$
\mathrm{R}_{\mathrm{it}}=\alpha_{\mathrm{i}}+\beta_{\mathrm{i}} \mathrm{R}_{\mathrm{nt}}+\varepsilon_{\mathrm{i}}
$$

Where :

$\mathrm{R}_{\mathrm{it}} \quad$ : Company return in period $\mathrm{t}$

$\mathrm{R}_{\mathrm{mt}}$ : Market return in period $\mathrm{t}$

(Hartono, 2003)

The beta in this study was corrected by the beta bias correction model of Fowler and Rorke's correction method with three leads and three lags. This model is able to correct beta bias in developing capital markets (Hartono and Surianto, 1999).

4. $\quad$ Profit Growth (X2)

$$
\text { Market to book ratio }=\frac{\text { Market value per share }}{\text { Book value per equity sheet }}
$$

(Collins dan Kothari, 1989)

\section{Financial Leverage (X3)}

$$
D E R=\frac{\text { Total Debt }}{\text { Total Equity }} \times 100 \%
$$

(Sukamulja, 2017:51), (Darmadji dan Fakhruddin, 2011:158)

Data analysis techniques in hypothesis testing using path analysis is an extension of multiple linear analysis so that in analyzing the data will follow the general assumption of linear regression. Through this path analysis can be found which path is more precise and brief an independent variable towards the final dependent variable, whether it must be through a direct path or must go through an intervening variable (Sugiyono, 2015: 14). Before testing hypotheses, the classic assumption test will be done first, namely the normality test, multicollinearity test, homoskedasticity test, and autocorrelation test. Next, regression is carried out in the following 2 structural equations: 
International Journal of Business Management and Economic Review

Vol. 4, No. 06; 2021

ISSN: 2581-4664

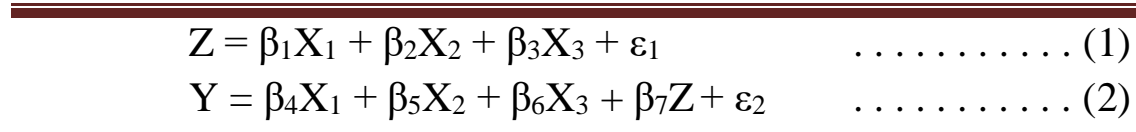

Where:

Z: Stock Return

Y: ERC

$\beta 1$ : Coefficient of the company's risk path with stock return

$\beta 2$ : Coefficient of profit growth path with stock return

$\beta 3$ : The financial leverage path coefficient with stock return

$\beta 4$ : Company risk path coefficient with ERC coefficient

$\beta 5$ : Coefficient of profit growth path with ERC coefficient

$\beta 6$ : The coefficient of the financial leverage path with the ERC coefficient

$\beta 7$ : Coefficient of stock return path with ERC

$\varepsilon 1$ : Residual for stock return

ع2: Residual on ERC

\section{FINDINGS AND DISCUSSIONS}

The normality test results obtained that the actual data spread far from the diagonal line, causing some data obtained to be not normally distributed so that the data will be converted into $\mathrm{Z}$ values with the SPSS program and issue data outliers with a confidence level of 95\% (Santoso, 2018 ; 204-217) . Thus, 182 observational data were obtained which were normally distributed according to the level of trust, which is where the lines describing the actual data are scattered around and follow the $\mathrm{Z}$ value line. , and the autocorrelation test has no problems. Then the results obtained from the regression of the two structural equations can be seen in Tables 1 and 2 .

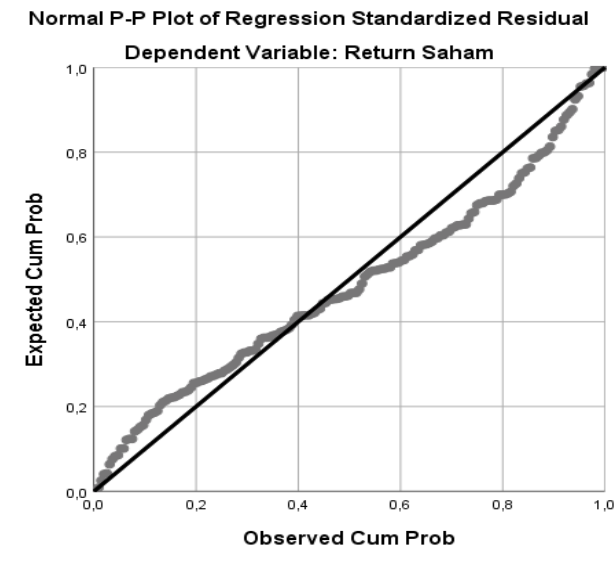

Figure 2. Normality Test Result Structural 1

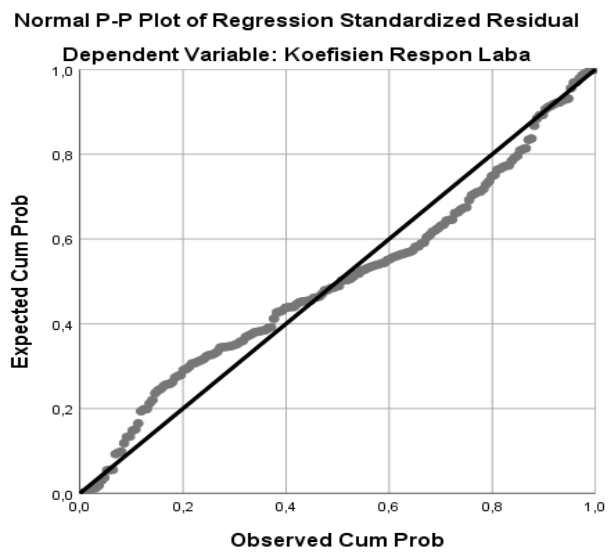

Figure 3. Normality Test Result Structural 2.

Table 1. Results of Structural Equation Regression 1 
International Journal of Business Management and Economic Review

Vol. 4, No. 06; 2021

ISSN: 2581-4664

\begin{tabular}{|c|c|c|c|c|c|c|c|}
\hline \multirow{2}{*}{ Model } & \multicolumn{2}{|c|}{$\begin{array}{l}\text { Unstandardiz } \\
\text { ed } \\
\text { Coefficients }\end{array}$} & \multicolumn{2}{|l|}{$\begin{array}{l}\text { Standardize } \\
\text { d } \\
\text { Coefficients }\end{array}$} & & \multicolumn{2}{|c|}{$\begin{array}{l}\text { Collinearity } \\
\text { Statistics }\end{array}$} \\
\hline & B & $\begin{array}{l}\text { Std. } \\
\text { Error }\end{array}$ & Beta & $\mathrm{t}$ & Sig. & $\begin{array}{l}\text { Tole } \\
\text { ranc } \\
\mathrm{e}\end{array}$ & VIF \\
\hline 1 (Constant) &,- 077 & ,078 & &,- 981 & ,328 & & \\
\hline $\mathrm{X} 1$ = Risiko Perusahaan &,- 021 & ,007 &,- 218 & $-3,231$ & ,001 & ,998 & 1,002 \\
\hline $\begin{array}{l}\text { X2 = Pertumbuhan } \\
\text { Laba }\end{array}$ & ,118 & ,021 & ,383 & 5,596 &, 000 & ,971 & 1,030 \\
\hline $\begin{array}{l}\mathrm{X} 3 \quad=\quad \text { Financial } \\
\text { Leverage }\end{array}$ & ,014 & ,012 & ,078 & 1,141 & ,256 & ,969 & 1,032 \\
\hline $\begin{array}{l}\mathrm{R}=0,435 \\
\text { F-Statistic }=13,882\end{array}$ & $\begin{array}{l}\text { Square } \\
\text { rob. (F- }\end{array}$ & $\begin{array}{l}=0,190 \\
\text { atistic) }\end{array}$ & 0,000 & $\begin{array}{l}\text { justed R } \\
\text { rbin-Wa }\end{array}$ & $\begin{array}{l}\text { quare } \\
\text { on stat }\end{array}$ & $\begin{array}{l}0,176 \\
2,012\end{array}$ & \\
\hline
\end{tabular}

Source: Research data, processed (2018)

Table 2. Results of Structural Equation Regression 2

\begin{tabular}{|c|c|c|c|c|c|c|c|}
\hline \multirow{2}{*}{ Model } & \multicolumn{2}{|c|}{$\begin{array}{l}\text { Unstandardiz } \\
\text { ed } \\
\text { Coefficients }\end{array}$} & \multirow{2}{*}{$\begin{array}{l}\text { Standardize } \\
\mathrm{d} \\
\text { Coefficients } \\
\text { Beta }\end{array}$} & \multirow[b]{2}{*}{$\mathrm{t}$} & \multirow[b]{2}{*}{ Sig. } & \multicolumn{2}{|c|}{$\begin{array}{l}\text { Collinearity } \\
\text { Statistics }\end{array}$} \\
\hline & B & $\begin{array}{l}\text { Std. } \\
\text { Error }\end{array}$ & & & & $\begin{array}{l}\text { Tole } \\
\text { ranc } \\
\text { e }\end{array}$ & VIF \\
\hline 1 (Constant) & ,268 & ,084 & & 3,187 & ,002 & & \\
\hline $\mathrm{X} 1=$ Risiko Perusahaan &,- 017 & ,007 &,- 167 & $-2,286$ & ,023 & 943 & 1,061 \\
\hline $\begin{array}{l}\text { X2 = Pertumbuhan } \\
\text { Laba }\end{array}$ &,- 049 &, 024 &,- 157 & $-2,012$ & ,046 & ,826 & 1,211 \\
\hline $\begin{array}{l}\mathrm{X} 3 \quad=\quad \text { Financial } \\
\text { Leverage }\end{array}$ &,- 026 & 013 &,- 140 & $-1,936$ & ,054 & ,962 & 1,039 \\
\hline $\mathrm{Z}=$ Return Saham &,- 188 & ,080 &,- 184 & $-2,340$ & ,020 & ,810 & 1,234 \\
\hline $\begin{array}{l}\mathrm{R}=0,330 \\
\mathrm{~F}-\text { Statistic }=5,411\end{array}$ & \multicolumn{2}{|c|}{ R Square $=0,109$} & $=0,000$ & \multicolumn{3}{|c|}{ Adjusted R Square $=0,089$} & \\
\hline
\end{tabular}

Source: Research data, processed (2018) 


\section{International Journal of Business Management and Economic Review}

Vol. 4, No. 06; 2021

ISSN: 2581-4664

Based on Table 1 and Table 2 we can compile the model paths 1 and 2 as well as the following:

$$
\begin{aligned}
& Z=(-0,218) X_{1}+(0,383) X_{2}+(0,078) X_{3}+\varepsilon_{1} 0,81 \\
& Y=(-0,167) X_{1}+(-0,157) X_{2}+(-0,140) X_{3}+(-0,1584) Z+\varepsilon_{2} 0,891
\end{aligned}
$$

Based on Table 1 and Table 2, the following results are obtained:

1. The calculated $\mathrm{F}$ value in Table 1 is 13,882 with a significance level of $0,000<0,05$. Thus, it can be concluded that corporate risk, profit growth, and financial leverage jointly influence stock returns.

2. The calculated $F$ value in Table 2 is 5,411 with a significance value of $0,001<0,05$. This shows that company risk, profit growth, financial leverage, and stock returns affect the ERC together.

3. The influence of the company's risk on stock returns. The results of the data obtained indicate that the value of $t_{\text {count }}=-3,231$ with a magnitude of influence is $-0,021$ and the value of the path coefficient $(\beta)$ of $-0,218$ and the significance level of $0,001<0,05$, which means that corporate risk has a significant and negative effect on stock returns.

4. The effect of profit growth on stock returns. The results of the data obtained indicate that the value of $t_{\text {count }}=5,596$ with the magnitude of influence is 0,118 and the path coefficient value $(\beta)$ is 0,383 and the significance is $0,000<0,05$, which means that profit growth has a significant and positive effect on stock returns.

5. The effect of financial leverage on stock returns. The results of the data obtained show that the value of $t_{\text {count }}=1,141$ with the magnitude of influence is 0,014 and the path coefficient value $(\beta)$ is 0,078 and the significance level is $0,256>0,05$, which means that financial leverage does not have a significant and positive influence on stock returns.

6. The effect of company risk on ERC. The results of the data obtained show that the value of $t_{\text {count }}$ $=-2,286$ with the influence between variables of $-0,017$ and the path coefficient value $(\beta)=-$ 0,167 and the significance level of $0,023<0,05$, which means that corporate risk has a significant and negative effect on ERC.

7. The effect of profit growth on the ERC. The results of the data obtained show that the value of $t_{\text {count }}=-2,012$ with the influence between variables at $-0,049$ and the path coefficient value $(\beta)$ $=-0,157$ and the significance level of $0,046<0,05$, which means profit growth has a significant and negative effect on ERC.

8. The Effect of financial leverage on the ERC. The results of the data obtained indicate that the value of $t_{\text {count }}=-1,936$ with the influence between variables of $-0,026$ and the value of the path coefficient $(\beta)=-0,140$ and the significance level of $0.054>0.05$, which means financial leverage has no significant and negative influence on ERC .

9. The Effect of stock returns on the ERC. The results of the data obtained show that the value of $t_{\text {count }}=-2,340$ with the influence between variables at $-0,188$ and the value of the path coefficient 


\section{International Journal of Business Management and Economic Review}

Vol. 4, No. 06; 2021

ISSN: 2581-4664

$(\beta)=-0,184$ and a significance level of $0,020<0,05$ which means that stock returns have a significant and negative effect on ERC.

Baron and Kenny (1986) state that a variable can be said to be a mediator if the results of the path coefficient value are significant. The results of testing the intervening variables are as follows: 1. The Effect of corporate risk on ERC through stock returns. Based on the results of data processing which can be seen in Figure 4, it shows that company risk is proven to directly influence ERC because of the sig value. amounting to 0.012>0.05 and stock returns are also proven to be the mediating variable of the company's risk relationship to the ERC, which both arrows show the value of sig. $<0.05$.

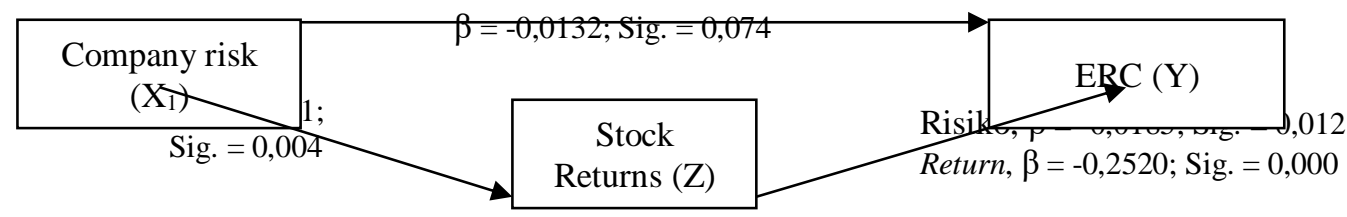

Figure 4. Analysis Diagram of Path $X_{1} \rightarrow Z \rightarrow Y$

2. The effect of earnings growth on ERC through stock returns. Based on the results of data processing which can be seen in Figure 5 shows that earnings growth directly does not affect ERC with sig values. amounting to $0.06>0.05$. Stock return variables are not proven to mediate the relationship between earnings growth against ERC because of the sig value. the relationship of stock returns to ERC is $0.0504>0.05$.

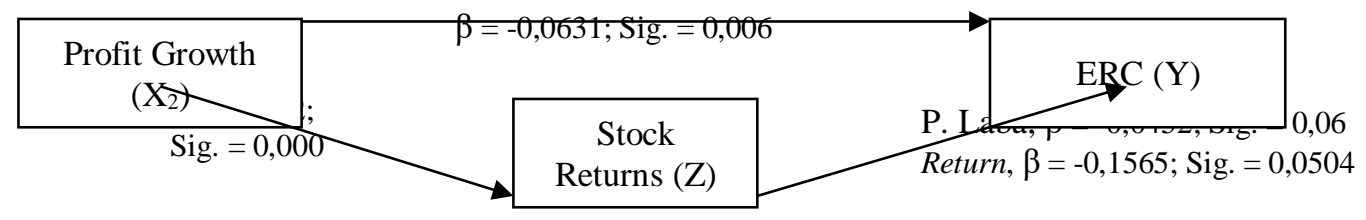

Figure 5. Analysis Diagram of Path $X_{2} \rightarrow Z \rightarrow Y$

3. The effect of financial leverage on ERC through stock returns. Based on the results of data processing, which can be seen in Figure 6, it shows that financial leverage has no effect on ERC either directly or indirectly with the stock return variable as mediation.

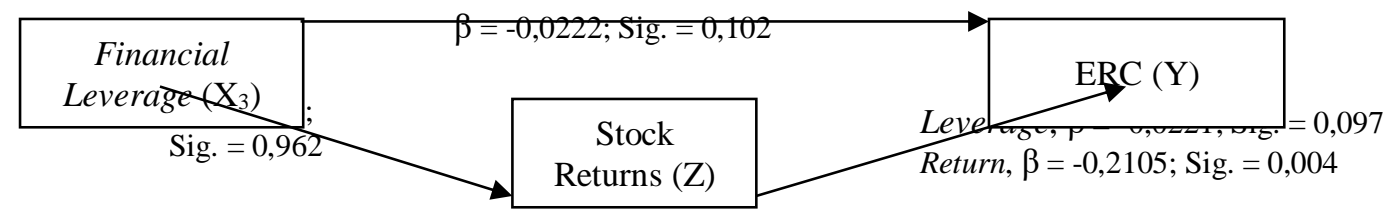

Figure 6. Analysis Diagram of Path $X_{3} \rightarrow Z \rightarrow Y$ 


\section{International Journal of Business Management and Economic Review}

Vol. 4, No. 06; 2021

ISSN: 2581-4664

\section{CONCLUSIONS AND RECOMMENDATIONS}

\section{Conclusions}

1. Company risk, profit growth, and financial leverage simultaneously influence stock return and company risk, profit growth, financial leverage, and stock return simultaneously influence the earning response coefficient.

2. Partially, company risk and profit growth influence stock return while financial leverage does not affect stock return.

3.Furthermore, company risk, profit growth and stock returns influence the earnings response coefficient as long as financial leverage does not affect the earnings response coefficient.

4.Then partially, stock retur mediate the relationship of the effect of company risk on earnings response coefficients and do not mediate the relationship between earning growth and financial leverage against earning response coefficients.

\section{Recommendations}

Further research is wisely recommended firstly to use longer research time with different objects so that the results of his research can be better revealed differences in each sector.

Secondly, next researchers can also use other variables such as company size, audit quality, conservative accounting, Corporate Social Responsibility (CSR), capital structure, financial performance, customer satisfaction, consumer trust, and consumer loyalty.

\section{REFERENCES}

Abror, M., \& Sadeli, D. (2014). Growth of cash flow, profit growth, inflation, interest rates, exchange rates, and stock returns in state-owned enterprises on the Indonesian stock exchange. Accounting and Taxation Research Journal, 1 (2), 171-186.

Arif, R.N. (2016). Factors that influence earnings response coefficient (erc) in companies listed on the Indonesia stock exchange (period 2011-2015). Institutional Repository Syarif Hidayatullah UIN: Faculty of Economics and Business. January 26, 2018. http://repository.uinjkt.ac.id/dspace/handle/123456789/49/browse?

type $=$ dateissued \&sort by=2\&order $=$ ASC\&rpp=100\&etal=7\&year=2016\&month $=12 \&$ starts with=

Ball, R., \& Brown, P. (1968). An empirical evaluation of accounting income numbers. Journal of Accounting Research, 6 (2).

Barli, H. (2016). Analysis of the effect of return on assets, profit growth, and leverage on stock returns (case studies on the property industry listed on the Indonesian stock exchange). University of Pamulang's Accounting Scientific Journal, 4 (1), 832-858. http://openjournal.unpam.ac.id/index.php/JIA/issue/ view/57/

Baron, R.M., \& Kenny, D.A. (1986). The moderators of the distinction variable in social psychological research: Conceptual, strategic, and statistical considerations. Journal of 


\section{International Journal of Business Management and Economic Review}

Vol. 4, No. 06; 2021

ISSN: 2581-4664

\section{Personality and Social Psychology, 51 (6), 1173-1182.}

Brigham, E.F., \& Houston, J.F. (2010). Fundamentals of financial management (Issue 11). Jakarta: Salemba Empat.

Collins D.W., \& Kothari, S.P. (1989). An analysis of intertemporal and cross-sectional determinants of earnings response coefficient. Journal of Accounting and Economics, 12, 143182.

Darmadji, T., \& Fakhruddin, H.M. (2011). Capital markets in Indonesia. Jakarta: Salemba Empat.

Delvira, M., \& Nelvirita. (2013). Effect of systematic risk, leverage and profit persistence on earning response coefficient (erc): Study of manufacturing companies that go public on the IDX in 2008-2010. WRA Journal, 1 (1), 129-154.

Diantimala, Y. (2008). The influence of conservative accounting, firm size, and default risk on earnings (erc) response coefficients. Journal of Accounting Research \& Research, 1, 102-122.

Harahap, S.S. (2010). Critical analysis of financial statements. Jakarta: Rajawali Press.

Harris, M., \& Raviv, A. (1990). Capital structure and the informational role of debt. The Journal of Finance, 45 (2), 321-349.

Hartono, J. (2003). Portfolio theory and investment analysis (Issue 3). Yogyakarta: BPEE Yogyakarta.

Heze, E. (2016). Net income is not a benchmark for investing. February 14, 2018. http://www.sahamgain.com/2016/11/laba-bersih-bukanlah-patokan.html/

Husiano, D. \& Suratno. (2008). Analysis of the influence of beta, leverage, dividend payout ratio, and earnings persistence on earnings response coefficient on the compass index 100. Research and Taxation Journal, 1 (2), 121-135.

Imroatussolihah, E. (2013). The influence of risk, leverage, growth opportunities, profit persistence, and the quality of corporate social responsibility towards earnings response coefficient in high profile companies. Management Scientific Journal, 1 (1), 75-87.

Indra, A.Z., Zuhron, A., \& Rosianawati, A. (2011). Analysis of factors that influence earnings response coefficient (ERC): Study of property and real estate companies listed on the Indonesian stock exchange. Journal of Accounting and Finance, 16 (1), 1-22.

Irawati, D.E. (2012). Effect of capital structure, profit growth, company size, and liquidity on earnings quality. Accounting Analysis Journal, 1 (2).

Jogiyanto, H.M. (2010). Portfolio theory and investment analysis (Issue 7). Yogyakarta: BPFEEUGM.

Mariani, N.L.L., Yudiaatmaja, F., \& Yulianthini, N.N. (2016). Effect of profitability and leverage on stock returns. Bisma E-Journal University of Education Ganesha, 4 (1). 30 July 2018. https://ejournal.undiksha.ac.id/index. php/JJM/issue/view/387

Murwaningsari, E. (2008). Simultaneous testing: Several factors that influence earnings response coefficient (erc). Updated on Data and Business Centers. Journal presented at the National Symposium on Accounting XI, Pontianak. 


\section{International Journal of Business Management and Economic Review}

Vol. 4, No. 06; 2021

ISSN: 2581-4664

Naimah, Z. (2008). The influence of company risk and leverage on the relevance of accounting profit values. Updated on Data and Business Centers. Journal presented at the National Symposium on Accounting XI, Pontianak.

Thank you. (2017). Effect of risk, leverage, growth opportunities, profit persistence, and quality of social responsibility towards earnings response coefficients in companies listed on JII. 28 February 2018. http://digilib.mercubuana.ac.id/manager/t!@file_artikel_abstrak/Isi_Artikel_357192317081. pdf

Financial Fervices Authority. (2013). Capital market statistics December - Sunday 4 2013. 14 February 2018. https://www.ojk.go.id/id/kanal/pasar-modal/data-dan-statistik/ statistik-pasarmodal/Pages/desember-minggu-4-2013.aspx

Putri, E.P., \& Azhari, M. (2017). Determinants of earnings response coefficients (empirical studies on consumer goods industry sector companies listed on the Indonesia Stock Exchange for the period 2014-2016). E-Proceeding of Management, 4 (3), 2350-2358.

Riyanto, B. (2011). Basics of company spending (Issue 4). Yogyakarta: BPEE.

Riyatno. (2007). The influence of the size of the public accounting firm on earnings response coefficients. Finance and Business Journal, 5 (2), 148-162.

Santoso, S. (2018). Mastering statistics with SPSS 25. Jakarta: Elek Media Komputindo.

Sari, N.I. (2014). 2013 became a gray year for the CSPI. February 14, 2018. https://www.merdeka.com/uang/2013-jadi-tahun-kelabu-bagi-ihsg-kaleidoskop-2013.html/

Scott, W.R. (2006). Financial accounting theory (2nd ed.). Canada: Prentice Hall Inc. Ontario.

Now, U., \& Bougie, R. (2017). Research methods for business: Skill-development approach (Issue 6). Jakarta: Salemba Empat.

Sugiyono. (2015). Statistics for research. Bandung: Alfabeta.

Sukamulja, S. (2017). Introduction to financial modeling and capital market analysis. Yogyakarta: Andi. 